Literature and the Secret of the World: 2666, Globalization, and Global War

Author(s): Patrick Dove

Source: CR: The New Centennial Review, Vol. 14, No. 3, Literature : Secret : World (Winter 2014), pp. 139-162

Published by: Michigan State University Press

Stable URL: https://www.jstor.org/stable/10.14321/crnewcentrevi.14.3.0139

JSTOR is a not-for-profit service that helps scholars, researchers, and students discover, use, and build upon a wide range of content in a trusted digital archive. We use information technology and tools to increase productivity and facilitate new forms of scholarship. For more information about JSTOR, please contact support@jstor.org.

Your use of the JSTOR archive indicates your acceptance of the Terms \& Conditions of Use, available at https://about.jstor.org/terms 


\title{
Literature and the Secret of the World
}

\author{
2666, Globalization, and Global War \\ Patrick Dove \\ Indiana University, Bloomington
}

THIS PAPER BEgAN TO TAKE SHAPE IN THE CONTEXT OF A CONFERENCE called "Literature and the Secret of the World." The conference organizer proposed a dual point of departure for reading the title: first, Jacques Derrida's assertion that literature is "the most interesting thing in the world, maybe more interesting than the world" (Derrida 1992, 47); second, the assertion in Roberto Bolaño's novel 2666 that in the serial murder of women in Santa Teresa lies hidden "the secret of the world" (Bolaño 2008, 348). My discussion of Bolaño's novel pursues the relation between literature, world, and secret, to which I add important considerations by Martin Heidegger and Carlo Galli concerning what gives with this thing called "world."

In a 2003 interview conducted shortly before his death, Bolaño described Ciudad Juárez-a city he reportedly never saw firsthand-as a contemporary

CR: The New Centennial Review, Vol. 14, No. 3, 2014, pp. 139-162. ISSN 1532-687X.

(C) 2014 Michigan State University. All rights reserved. 
and terrestrial version of hell, calling it "our curse and our mirror, the troubled reflection of our frustrations and of our monstrous interpretation of freedom and of desire" (Bolaño 2010, 29-30). The distant echoes of Plato's use of the mirror as metaphor for mimesis in the second book of the Republic are unmistakable. For readers of Bolaño's posthumous novel 2666 (2004; English translation 2008) that description provides an enticing point of departure for analyzing Bolaño's portrait of the fictive city of Santa Teresa. Located in the state of Sonora instead of Chihuahua, Santa Teresa displays many if not all of the recognizable traits of Juárez: it is a sprawling border town with a thriving máquila industry together with abundant sex and entertainment industries; and it is a major destination for migrants seeking employment as well as a nexus for transnational trafficking of people and narcotics.

For the moment I am going to pass over the distinction between Santa Teresa and Ciudad Juárez and treat them as if they were two names for the same thing. Later there will be occasion to look more closely at what is at stake in the composition of Santa Teresa as a literary space. Before delving into the myriad of epistemological and aesthetic questions that arise in relation to Bolaño's positioning of Ciudad Juárez as an unsettling mirror that would bring into view a certain truth about our world today, a preliminary query I want to pose concerns the "we" of whom Bolaño speaks (nuestra maldición y nuestro espejo). Is Bolaño appealing to an idea of Latin America as a region defined by shared interests and a shared history and that served as a laboratory for early experiments with neoliberal economic reform (Chile beginning in 1974; Argentina from 1976 to 1981) imposed by force following the violent interruption of revolutionary projects? Or does the "we" refer to a less geographically determinate idea of collectivity, as in the West or a global community that could be expected to feel concern and responsibility in view of the brutal treatment of working-class women as well as the culture of impunity and corruption that must be presumed to exist in light of the fact that the killer(s) have been able to carry on for years without detection or prosecution? The question about the "we" is not an issue of semantic clarification but a matter of the possibility or impossibility of thinking and naming totality and the common today, and of how what calls out to us in the name Ciudad Juárez in turn shapes how we think about our world today. Under the dim light of 
Ciudad Juárez, and to the extent that its reality is perceived as "unimaginable" in comparison with living conditions elsewhere, can we still speak of Juárez under the supposition that we have in common with it a world? Or does its unsettling, uncanny appearance precisely disrupt any possibility of conceptualizing the commonality of a network of significant relations?

Juárez is a symptom of the violent contradictions of late capitalism, putting on display the inability of neoliberal hegemony to resolve problems associated with long-standing structures of inequality in Latin America. ${ }^{2}$ The various forms of destruction that accompany the neoliberal-administered opening of national economies in Latin America to transnational capital are manifest in the horrors commonly associated with Ciudad Juárez, most notoriously in the relentless appearance of tortured, mutilated bodies of young women in the city, its suburbs, and the surrounding desert.

In Bolaño's description the key term that positions Ciudad Juárez as a mirror that would bring into view the unthought contradictions of the global system is the word libertad. Libertad refers explicitly to neoliberal theory and its powerful identification of unregulated economic opportunity with freedom. But the term also points up, through an ironic turn, the intensification of a real unfreedom that Marx originally associated with the origins of the free labor market: first with the violence of expropriation and separation and subsequently with the ideological legitimation of that violence through narratives of moral virtue. ${ }^{3}$ In the context of modern Mexico the idea that the truth of "freedom" is unfreedom takes on added weight with the decline of the Welfare State and with the opening of national economies to the unmediated flows of transnational capital, together with the proliferation of flexible employment and relocation practices in the time of post-Fordism. The Free Trade Zone of northern Mexico is a space of turbulence provoked by rapid economic growth together with the precariousness and intensified vulnerability under which the unskilled maquiladora labor force finds itself. "Freedom" is a euphemism for the reduction of the workforce to bare life exposed to the cruelties of the sovereign ban.

Although Juárez names a location that can be mapped within the modern geopolitical boundaries of Mexico, its specificity as a place is marked by the fact that its rapid growth in recent decades makes visible the crisis of state 
sovereignty. Juárez is synonymous with, among other things, new forms of capitalist accumulation, production and distribution aligned with neoliberalism and the North American Free Trade Agreement (NAFTA), and the rise of drug trafficking and cartel-related violence, including but not limited to the unsolved serial killings-the majority of whose victims have been women employed in the máquila and the sex industries. The rapid expansion of the máquila factories in the wake of NAFTA has transformed the social and demographic landscape of northern Mexico, disarticulating traditional forms of collectivity while attracting new waves of migrant populations from elsewhere in Mexico and Central America in search of readily available jobs. This rapid demographic growth is accompanied by a new phenomenon of social anonymity. As Bolaño's 2666 frequently reminds us, neoliberal economic growth in northern Mexico leads not to social stability but to new forms of vulnerability-especially among working-poor women-and an intensification of anomie.

Carlo Galli has proposed that in the time of globalization and global war any clear distinction between war and politics - two spheres that have until now been entrusted to the national state-becomes increasingly difficult to sustain (Galli 2010). This is clearly the case for the United States and its European allies, for whom almost all aspects of domestic and foreign political affairs are now shaped by the specter of an "endless war" that, in its very inaugural justification, suspends the old distinction between times of war and peace. It is also increasingly the case in countries such as Mexico that, while not directly involved in the ideological and military conflicts associated with 9/11 and its aftermath, have nonetheless begun to confront their own problems with "terrorism"-including the material reality, the ensuing state of insecurity, and the politics of defining terrorism and distinguishing it from lawful violence.

While the growth of the máquila industries coincides with the dismantling and retreat of the state's historical role as mediator between the local and the capitalist world system, the more recent narco wars illustrate how the state is now unable to guarantee order and security through monopolization of the legitimate means of physical force. ${ }^{4}$ One of the consequences of the dramatic increase in narco violence in northern Mexico during the first decade of the 
twenty-first century is that the distinctions between law and illegality, order and insecurity, are becoming less clear and less stable. This blurring of conceptual borders separating the realm of politics from the domain of war is the hallmark of what Galli calls global war (Galli 2010). While the police and army are now-once again-accused of employing the tactics of terror and committing widespread human rights abuses against known and suspected cartel members, one former cartel hitman recounts how the best and brightest of the Chihuahua police academies find employment not with local law enforcement but precisely in the cartels they have been trained to combat (Bowden and Molloy 2011, 73-82).

The major factors I have been discussing - the opening of national economies to transnational markets, the fulfillment of neoliberal privatization, and the escalation of the drug wars-are not unrelated. The spread and intensification of narco violence began with the election of Vicente Fox in 200o, which broke the seven-decade Partido Revolucionario Institucional (PRI) hegemony and led to the dismantling of existing arrangements between the cartels and the PRI state. The sudden disruption of structural equilibrium between the cartels and the Mexican state led both to a new proliferation of corruption at the local level-the cartels were suddenly obliged to forge new arrangements with local legal and political institutions-and an intensification of violence between rival cartels competing for new territory. In 2006 Fox's successor, Felipe Calderón, intensified the crackdown on the cartels by deploying federal troops in Michoacán and other regions for the first time in the conflict. Calderón's militarization of the situation quickly escalated into an undeclared war between the cartels and the Mexican state (Bussey 2008).

If Juárez is a mirror for us today, as Bolaño suggests, it is not because it is the part that represents the whole in the old sense, that is, a postmodern inversion of the old culturalist paradigm that presented Europe as embodying a developmental truth of which the periphery was a mere copy or a delayed variant. It illuminates a limit for the political geometry of modernity. Our modern political vocabulary, which is grounded in the concepts of national and state sovereignty, is unable to account for what is happening in the world today. Juárez puts on display the unsettling fact that, in the words of Galli, "the external seems to have become internal" (Galli 2010, 139). Juárez, we could say, 
is the point on the map that without fail directs our attention to both the map as a whole as well as the conceptual basis for modern political cartography, both of which have now become inoperative. As a nodal point for an array of new exchange circuits and trafficking flows, Juárez is the contorted and mutilated image that exposes the fractured nonunity of what used to be the sovereign nation-state.

There is an additional layer of irony inherent in Bolaño's characterization of Ciudad Juárez as an uncanny or disconcerting but revealing mirror: one of the new tendencies that comes to light at this site is that the old epistemological pairings of revelation and concealment, masking and unmasking, appearance and truth, prove ineffective for understanding our current situation. Why so? Because in Mexico, among other places, it would seem that everything is increasingly out in the open and interconnected-or torn asunderunder the double rubric of globalization and global war: the predatory power of transnational corporate and financial capital thriving in the retreat of the regulatory state; an army that knows no restraints or oversight and whose tactics resemble those of a terrorist organization; and the cartels that act like mini-states, claiming territory in Mexico and Central America using militarygrade weaponry and recruiting soldiers-not through ideology but with paying jobs-from among the growing ranks of unemployed and undertrained and, increasingly, from disaffected adolescents who have been abandoned by a collapsing educational system (González Rodríguez 2012; Beckhusen 2013). Even the state appears willing to embrace the thesis of global war, as suggested by a November 2012 petition issued by the president of Costa Rica on behalf of the Organization of American States requesting that the United Nations begin categorizing drug trafficking as a form of terrorism (Fendt 2012). If Oliver North and Iran-Contra exposed the secret connection between politics, counterinsurgency terror, and the drug trade, what was once a Cold War secret is now out in the open for all to see in the time of global war.

Neoliberal privatization and global war together comprise a new situation in which the modern concept of state sovereignty and the friend/enemy distinction are no longer capable of accounting for the way the global capitalist system works-and sometimes seems on the verge of breaking downtoday. The modern state form with its institutional, juridical, and ideological 
presence no longer serves as katechonic regulator of its own borders in relation to global ebbs and flows of capital, telecommunications, migrant populations, and contraband. ${ }^{5}$ Global war suspends the old distinctions between wartime and peacetime, war and politics, while also putting an end to the principial status formerly held by state sovereignty. In that light, thinking's access to what Heidegger would call the worldliness (Weltlichkeit) of our world may well also need to be reexamined today (Heidegger 2010, 63-110).

In speaking of world I have in mind neither the globe nor a sum total of entities but a structuring of sense, reference, and relations of cobelonging that underlies and makes possible any meaningful experience of totality. The question I want to explore here concerns the manner in which the economic, political, and technologically driven unifying and leveling effects of neoliberal globalization also generate a disarticulation of ontological-existential structures of relationality, or of what Heidegger in Being and Time calls the structure of reference (Verweisung) presupposed in the thought of world (Heidegger 2010, 68-88). No doubt globalization today announces the dismantling of an old referential frame and the imminent emergence of new modes of arranging bodies, goods, and collectives in relation to one another. But does this new framing of distributions, circulations, and belonging still constitute a world, as Heidegger understands it, or does it instead produce what Jean-Luc Nancy calls an "enclosure in the undifferentiated sphere of a unitotality" (Nancy 2007, 28), that is to say a totality in which all difference has been subsumed under a logic of equivalence, and all gaps and absences have been filled up, with no possibility for the emergence of anything truly new? Do the iniquities and violence of Juárez bring into view the truth of our world, whether we wish to acknowledge it or not? Or, if the world worlds, as Heidegger suggests in "The Origin of the Work of Art" (Heidegger 1971, 44), would Juárez in turn attest to the unworlding of our world in a time when all openings for creation are subsumed within global capital's calculative logic of equivalency and overwhelmed by the logic of instrumentality? This, I propose, may be the major unarticulated question that haunts 2666; it is the true "gran tiburón negro" (great black shark) that lurks beneath the grammatical surface of Bolaño's novel and for which the critics' pursuit of Archimboldi plays the role of stand-in (Bolaño 2004, 25). ${ }^{6}$ The question I am pursuing here concerns 
the very real possibility that the prevailing logic of neoliberal globalization generates an enclosure within which infinity or alterity can be easily captured and subsumed within hegemony. A few words about Heidegger's treatment of world may help to make this point clearer; while this clarification will help establish what is at stake in Heidegger's reflections on world, it may also help illustrate why this liminal question about Juárez and the future of the world does not meet with any definitive answer in Bolaño’s novel.

World, as Heidegger clarifies in chapter $3, \$ 16$ of Being and Time, is "not an innerworldly being, and yet it determines innerworldly beings to such an extent that they can only be encountered and discovered and show themselves in their being, insofar as 'there is' [es gibt] world" $(2010,72)$. World refers not to a collection of objects and beings but to a structure of reference that logically precedes the entities that populate a world and brings them together, allowing them to be perceived (and act) as beings. Reference, in Heidegger's sense, refers to the specifically practical assignations and relations via which the entities of our world take on specific values or meanings while also being brought together and related to one other as the interrelated parts of a totality. Heidegger's formulation, es gibt world, literally says "it gives world," as opposed to the association of world with being, as in "there is a world." The German grammar highlights that it is this prephenomenal inscription of referentiality that allows for the assignment of specific meanings to beings and to the fundamental concepts through which we understand our world (being, belonging, etc.). It is referentiality that defines the possibilities for thinking and acting within a given world.

Let me offer a Heideggerian anecdote to clarify what I am getting at here: In division 1, chapter 3 of Being and Time, entitled "The Worldliness of the World," Heidegger asserts that the world we inhabit first manifests itself to us not as objects in general (res) but as that specific class of object known as tools (pragmata). Our experience and understanding of our world is first and foremost "equipmental" in nature. ${ }^{7}$ In our daily lives we move about in equipmentally defined spaces in which things are perceived as tools that are ready to hand. Heidegger's assertion that equipmentality is what gives the possibility of world is supported by the grammatical fact that we never speak of "an equipment"; we only speak of equipment in the plural. But the worldliness of 
the world-or the ontological-existential structuring of totality-remains an elusive secret both to everyday consciousness and to the ontological inquiries of the philosophical tradition. On one hand, the practical character of referential relations strongly suggests that any awareness of the totality within which we find ourselves will be outweighed by pragmatic concerns. After all, it would be a poor craftsperson who lets her- or himself get distracted from the tasks at hand by the fundamental questions of philosophy. On the other hand, when ontology does ask about the world it is programmed to inquire about the world's nature or essence. But in formulating its inquiries in this way, ontology necessarily overlooks the possibility that to ask questions about a hidden "nature" or "essence" is already to be situated within a particular, constituted frame of reference: the ti esti of metaphysics, the "what it is" concerning a given being or the question about essentia or essence. When it comes to thinking the worldliness of the world, Heidegger asserts, traditional ontology "is at a dead end-if it sees the problem at all" (Heidegger 2010, 65). Ontology's inquiries are founded on an originary "forgetting" or foreclosure of the fact that thought always finds itself already within a referentially structured world, and that its intentional representations and questions about entities and objects have themselves already been framed by a structuring of sensibility, meaning, and usefulness that delimits in one direction or another the horizon for thinking.

The worldliness of the world constitutes a secret register that remains inaccessible to ontology in its traditional configurations. Where we do have a chance of experiencing the secret of the world or its worldiness, Heidegger tells us, are in those rare moments when referential networks are interrupted or suffer breakdowns. For example, in a carpenter's workshop it is immediately clear how everything is first and foremost a tool that has its proper place and function; it is so obvious, in fact, that we rarely give it a moment's thought. Each individual tool is defined a priori by its relation to other tools (the hammer in relation to nails, the saw in relation to the lathe) and, moreover, in relation to an entire production process within which everything has been assigned a specific and relative meaning or purpose. It is within the world of the workshop, then, that the hammer first appears as a hammer. All of this goes without saying, and that makes the carpenter's practice akin to a second 
nature. In this example it is just a carpenter's shop, but one could also think of the referential structuring of a society, a community of national states, or the planet. It is when something happens to disrupt the smooth functioning of referential order in which everything has its place that we suddenly and for the first time experience referentiality and worldliness. For instance, the hammer unexpectedly breaks, and it is only then, in our irritation in the face of what does not work that we become aware of having a world.

I propose, as a working hypothesis, that Bolaño's literary treatment of Ciudad Juárez seeks to illuminate such a moment of interruption in the context of the ordering principles of modernity. With its wide range of figurations of evil, 2666 invites us to consider Santa Teresa as the visible form that accompanies the lifting of all restraining structures or katechon. With that in mind let us now turn to the question of "literature and the secret of the world." The phrase "the secret of the world" is taken from an internal monologue that Fate carries on as he drives through the desert back to the United States: "No one pays attention to these killings, but the secret of the world is hidden in them. Did Guadalupe Roncal say that, or was it Rosa? At moments, the highway was like a river. The suspected killer said it, thought Fate" (Bolaño 2004, $439 ; 2008,348)$. This formulation about the secret of the world supports two contradictory modes of inquiry.

On one hand it says that the Juárez murders hold the key for deciphering what is going on in, and going terribly wrong with, the world today. The assignment of some phenomenal content to the secret coincides with what is known, genetically speaking, about Bolaño's approach to writing 2666 and especially his focus on the crimes. According to Marcela Valdés the Juárez murders first captured his attention in the mid-1990s, at a time when they had yet to become a focal point for international media and when information about the killings was difficult to come by (Valdés 2008). ${ }^{8}$ The context described by Valdés lends credence to the view that Bolaño saw his novel as an exposé and denunciation of certain dirty truths about neoliberalism and the Mexican legal and political systems. The disposability of human "detritus" in Juárez would provide the key for carrying out a critical analysis of global capitalism. Bolaño's novel would thereby situate itself within the literary genres and subgenres associated with the figure of the detective, and Santa 
Teresa would take shape as a gigantic crime scene. Indeed the detective figure does seem to multiply almost beyond all limits in 2666, beginning with the critics in their search for Archimboldi and then picking up again with the procession of police and private investigators including Fate, Sergio González Rodríguez, Kessler, Juan de Dios Martínez, Lalo Cura, Klaus Haas-who is compared to Isidoro Parodí, the fictive detective created by Borges and Bioy Casares (Bolaño 2004, 786; 2008, 629) - as well as all the others seeking to discover the identity of the killer(s).

On the other hand, what if the phenomenal status of the secret is not so clear-cut? As soon as one finds oneself compelled to abandon the theory of the single, diabolical serial killer, the association of the secret with a phenomenal content becomes difficult to sustain. What if the secret of the world were not a reference to something that had been hidden from view or passed off as something it is not and which could therefore be brought into the light of day? What if the secret named a withdrawal or hiatus or opacity that was constitutive of all appearing, constitutive of the totality that we call world, and thus before any determinate presence? In that case, to inquire into the content of the secret would be to miss the point and would only take us further and further away from the truth of the secret. The phrase could also be read as stating that Juárez is the site where the secret of the world hides itself (esconderse), with emphasis on the near-redundancy of the substantive secreto (from the Latin secretus: set apart, withdrawn; hidden, concealed, private) and the reflexive verb esconderse (from the Latin abscondere: to hide, conceal, to bury, immerse, to engulf, to keep secret). If Juárez is the site where the (always already mysterious or secret) emergence of a globalized world is somehow able to conceal itself, then perhaps we should not conclude too hastily that this site harbors a phenomenal truth that could be disclosed. In approaching Juárez as harboring some knowledge that awaits discovery, we would render ourselves blind to the role that secreting plays within the structuring of referential totality. Symptomatic reading would display its own limit here when it designates as contingent-and then proceeds to push beyond-the mechanisms of dissimulation or the movement of withdrawal that generates the secret in the first place. The difference between these two readings does not amount to a choice between hermeneutics and something else; it is a distinc- 
tion between two hermeneutic understandings of what is at stake in the ideas of surface and appearance. Traditional hermeneutics views surfaces as false appearances that need to be stripped away like the layers of an onion until the hidden truth is finally uncovered; the alternative hermeneutic approachone that I am proposing that Bolaño's text invites us to take up-would investigate the surface as a nontransparent medium in which appearance and dissimulation are sometimes at work simultaneously. Poe's "Purloined Letter" would be one example of a text that aligns itself with such a hermeneutics, and I would like to propose that Bolaño follows in that vein.

While there is nothing wrong with a traditional hermeneutic approach to 2666 that relies on the old distinction between appearances and truth, surface and depth-and such an approach is almost certainly unavoidable-it is also inadequate for several reasons. First, because as any reader of Bolaño knows, his texts are acutely aware of their own literary status as objects available for interpretation. Not unlike the Minister in Poe's "Purloined Letter," it may be that Bolaño's texts have already taken the step of accounting for criticism's accustomed investigative procedures. In that case critical interpretation would proceed at the risk of tripping over its own feet and discovering that it has been a dupe of its own intelligence. The truth loves to hide: thus reads the axiom of traditional investigative reason, whether it is literary, scientific, or police. But what if criticism were to meet with a worthy opponent versed in the game of deception and obfuscation, capable of inserting itself in the place of critical intelligence, who opted instead to leave the truth lying out in the open and exposed for all to see-except, of course, for the critic whose perception is attuned exclusively to the realm of concealment? Could the truth then be said to have been hidden out in the open? Here we have a question that neither traditional hermeneutics nor recent announcements of a postsuspicious "surface reading" are able to confront. ${ }^{9}$

There is another reason why the old hermeneutics of surface versus depth may prove inadequate for unpacking this formulation of the secret, and it is this that I want to focus on in the second half this paper. It may be that the staging of resistance to traditional modes of interpretation in Bolaño's novel partakes in a general law concerning literature and the secret, and that the secret to which the novel alludes refers not a phenomenal content waiting to 
be uncovered but to a limit for interpretation and reading. The secret, as the name for an interpretive limit, would be neither inside nor outside of literature and of the territory available to critical investigation.

Derrida has written extensively on the matter of literature and secrecy, although the extensiveness would need to be qualified in view of his claim that, if what we call literature meant to say anything at all, it would be that "there is no-or hardly any, ever so little-literature" (Derrida 1981, 223). And yet, alongside that profession of reserve when it comes to theorizing about literature, Derrida can also assert elsewhere that "literature perhaps stands on the edge of everything, including itself. It's the most interesting thing in the world, maybe more interesting than the world" (Derrida 1992, 47). What is going on in this apparent contradiction whereby an object whose very being has been cast into doubt also-and almost sacrilegiously-emerges as the most interesting of all? We should take the ambivalence manifested in these conflicting statements as providing a frame for thinking the literary: as both approaching nothing and as associated with an interest that comes close to overflowing the totality we call world.

The claim that "there is no-or hardly any, ever so little-literature" can be parsed taking any one of several emphases as our guide. There is, for example, the historical fact that what we today call "literature" is of relatively recent invention, dating back no earlier than the beginning of the nineteenth century with de Staël's essays on literature and national culture and with the Jena Circle's reflections on the fragment and the "literary absolute." ${ }^{10}$ Moreover, the history of its pre-Romantic predecessors (poetry, belles lettres, etc.) is thoroughly entangled with nonliterary histories, including the evolution of mediatic technologies (printing press, cybernetics, digital media), and the development of legal codes (copyright and intellectual property law). Thus the so-called "field" of literature has always been contaminated by one or another nonliterary outside.

In the "there is no" there is also the echo of another thought of uncertainty concerning the ontological status of the literary object. Recall the well-known conceit exemplified in Plato's Republic about literature as a second-order mimesis that effectively erases the distinction between original and copy. As a generator of simulacra, literature both distorts the truth for dramatic effect (it 
tells tall tales about the gods resorting to deception and heroes throwing tantrums), and in the same deft gesture it lures our attention away from the distance that separates the phenomenal appearance from the eternal idea, seducing us into believing that what are in fact mere copies-or worse: copies of other copies-could somehow be in possession of their own truth. Plato's decision to ban the poets from the city is predicated on the association of literature with a risk of mimetic contagion and contamination that philosophy finds intolerable. Literature's spell poses a dire threat to the fundamental metaphysical mode of inquiry, the to ti esti. Literature forms a strange and estranging space in which metaphysics discovers that its attunement to the voice of being has been interrupted, and in which the metaphysical mode of inquiry is thereby made to tremble. Here we find an especially promising way of working through the enigmatic formulation about literature and the secret of the world: the literary names an experience of language that brings traditional ontology to a halt; in arresting the to ti estiline of questioning or causing it to waver, the literary effects in the metaphysical tradition something analogous to what Heidegger describes as the breakdown of reference that in turn brings us into confrontation with the fact that there is a world.

And yet there is no simple choice or alternative between metaphysics and literature, between the to ti esti and the literary. It is only beginning in the nineteenth century that literature begins to take up this long-perceived threat as its own proper concern: the question of the literary as such. The historical emergence of literature coincides with a turning away from traditional mimetic views of language to focus on its own formal arrangement and language. Literature becomes interesting to itself (and, by the same token, to theory) precisely because it cannot be said to possess an essence, and because its nonresponse to the to ti esti, together with that the literary is not simply nothing either, exposes traditional ontological inquiry and metaphysics to its own unthought ground-or better, its nonground. The literary thereby unleashes a nothing-ing that ruins the distinction between being and nothingness. This literary turn is not itself free of complications and paradoxes, however. We could say that the status of literature has never been in as much doubt as it is in the time of literary modernity and its characteristic obsession with the literary. If there is "hardly any" literature, this may be in part because 
it is nearly impossible to say with any certainty where "literature" begins and ends, either diachronically or synchronically speaking. Literature in turn takes this "hardly any!" as its own point of departure and as the source of its passion. But literature cannot inhabit such a self-reflective position for long. As Derrida puts it,

If there is no essence of literature-i.e., self-identity of the literary thing-if what is announced or promised as literature never gives itself as such, that means, among other things, that a literature that talked only about literature or a work that was purely self-referential would immediately be annulled. You'll say that that's maybe what's happening. In which case it is this experience of the nothing-ing of nothing that interests our desire under the name of literature. Experience of Being, nothing less, nothing more, on the edge of metaphysics, literature perhaps stands on the edge of everything, almost beyond everything, including itself. $(1992,47)$

The modern literary inclination toward self-reflection-exemplified in the works of Mallarmé, Joyce, Kafka, Borges and others-leads, if taken to its extreme, in the direction of a vanishing of the literary object, its becoming indistinguishable from sheer noise or illegibility. By the same token, selfreference presupposes that the subject-object of reflection indeed has a determinate whatness. If literature is that which has no proper qualities of its own, then self-reference could only constitute an empty gesture that never manages to realize itself and is always in the process of displacing itself. Literature in its self-reflective mode remains unable to grasp or make visible the object to which it would refer. It is as if the literary could only be discerned in its quiddity when viewed obliquely and through the blurriness of peripheral vision; as with Orpheus and his venture to recover Eurydice, any attempt to grasp literature in its whatness can only end in the loss of the literary object. That "there is no literature" is a formulation of this paradox of self-reflection and dissolution: when literature turns back to itself, either it has not yet fully come into view or it has already vanished. Here we are not far from Borges's account of the aesthetic act as "the immanence of a revelation that does not take place" (Borges 1974, 13). 
Before moving on to the second formulation I want to pause briefly over a curious equivocation in the phrase "there is no-or hardly any, ever so littleliterature," a hesitation between what simply does not exist and what is rare. One way to approach this ambiguity is to treat it as signaling a fold within the modern experience of literature. Such a fold would attest, on one hand, to the paradoxical nature of literary self-reflection that we have just been looking at, that is, the more self-reflective it gets the closer literature comes to its own vanishing point, its dissolution into noise or its fall into the abyss of an empty mirror. Self-reflection might be the goal of modern literature, but that tendency-which is nothing other than the mark of the modern Subjectshould not cause us to lose sight that there can be no literature that does not also fall prey, in one form or another, to the gesture toward transcendence: toward language becoming signification again, toward readings that are governed by the endeavor to uncover a hidden signified (even if this signified as "literature as such"), and so on. On the other hand, this same fold also describes the modern tendency to discover the literary in what are nominally nonfictive, noncreative cultural forms (autobiography, film, political speeches, journalism, advertising, and so on). In that light, the statement that "there is no-or hardly any" would denote not the unresolvable ontological problem of literature's (non)essence but the fact that aesthetic and political modernity are informed by a proliferation of the literary that at once prompts new efforts to track and govern its movements while at the same time always threatening to become ungovernable. ${ }^{11}$ In that light the negation in the "there is no" clause could be explained as modernity's potentially unlimited expansion of the literary, the proliferation of a way of reading the world that attends not to the transcendent movement of signification but to the "materiality" (de Man) or "insistence" (Lacan) of the letter itself. ${ }^{12}$

This seeming contradiction in which literature remains caught points us in the direction of the secret of literature: the secret in literature but also the secret of literature, which as we will now see turn out to be different variations on the same law. The secret I am interested in pursuing with Bolaño's formulation has nothing to do with the withholding of this or that meaning, either in relation to Santa Teresa/Ciudad Juárez or having to do with the text and/or with literature in general. This secret names a silence or reserve that inhabits 
every literary phenomenon in one form or another, although it cannot be said to withhold anything of substance; nor for that matter should silence or retreat be thought to constitute part of literature's definition or essence. Before any consideration of its possible content, the secret simply names an unavoidable remnant of unpresentability—this residue could be relatively minor or substantial in scope-that remains in the wake of any reading of a literary text, no matter how attentive or exhaustive it may be. Are there other ways of pursuing the formulation about the secret in Bolaño's novel? No doubt. My intention is not to rule out other possible readings of the phrase in question but only to suggest a line of interpretive work that seems to me especially productive and compelling in relation to Bolaño's novel.

The secret of literature, for Derrida, resides in an "infinite power to keep undecidable and thus forever sealed the secret of what it says, or even that which it avows and which remains secret, even as in broad daylight it avows, unveils or claims to unveil [the secret]. The secret of literature is thus the secret itself. It is the secret place in which [literature] establishes itself as the very possibility of the secret, the place it, literature as such, begins, the place of its genesis or of its genealogy, properly speaking" (Derrida 2008, 18; emphasis mine). It is of the structure of literature to generate accounts, statements, and images for which the corresponding intention remains unknown and unknowable to the reader. Traditional literary criticism dedicates itself, using one set of methods or another, to uncovering or deciphering the meaning that it suspects remains hidden or secreted away beneath the furrows of the page. However, by approaching those sites where literature announces that it has a secret and investing them with a positive content that could be discovered, criticism ritualistically forgets the possibility that the form of the secret does not contain any determinate content or that the form/content distinction itself does not apply in such cases.

Let us take as an illustrating example from 2666 the concluding scene in "The Part about Fate" in which Fate and Rosa Amalfitano accompany Guadalupe Roncal on her mission to interview Klaus Haas, one of the leading suspects in the murders, in prison. The narrative account of that visit is interrupted just as the towering, blond-haired "giant" walks into the visitor's room, with Roncal raising her hand to her mouth in an ambiguous gesture that Fate 
interprets as either indicating a sudden lack of oxygen ("as if she were inhaling a toxic gas") or as signifying a complete lack of ground on which to commence the interview ("she couldn't think what to ask") (Bolaño 2004, 440; 2008, 349). "The Part about Fate" thereby culminates in a knot of literary secrets that must perforce remain buried in the crypt that is Santa Teresa's jailhouse: What, if anything, did Roncal finally muster up the courage to ask the terrifying giant? What, if anything, did they learn from Haas about the murders? Is he in fact being framed, as the narrative discourse sometimes insinuates? If so, by whom? Whereas Derrida has discussed the secret of literature in the context of fictional narratives based on reported dialogues (e.g., Poe's "The Purloined Letter" or Baudelaire's "Counterfeit Money"), in the case of 2666 the association of literature with the secret is not attributable to the structural limits inherent to the specific subgenre of reported dialogue, that is, the impossibility of knowing whether the interlocutor's discourse-filtered through a double or triple mediation: a telling that is retold by another after the fact-truly aligns with what he or she actually did, meant, or meant to do. With Bolaño, by contrast, the secret finds its structure in the figure of the crypt (the jail cell and the unmarked grave, among others), from which it would seem that nothing can escape. While a naive reading might debate endlessly the question of Haas's guilt or what Roncal learned from her interview with him, the only discernible facts are that we can never know the answer to those questions and that, even if it were somehow possible to ascertain Bolaño's opinion on the matter (e.g., if someone were to discover notes by the author indicating plans for an unrealized portion of the novel), that knowledge would change nothing about the text we have in front of us. "The Part about Fate," as it currently stands, is not incomplete. On the contrary, it is clearly and indisputably complete, its completion deriving precisely from the kind of sudden narrative interruption that Ignacio Echevarría, in the introduction to a posthumous collection of short stories also associated with the question of evilEl secreto del mal (The Secret of Evil) - aptly terms the "poetics of inconclusiveness" (Bolaño 2013, 9).

Brett Levinson (2009) makes an important contribution to our awareness of the problems of interrelatedness and disassociation in 2666, and I would propose that the fundamental impasse he identifies concerning the connec- 
tions between parts of the work in 2666 can be extended to the question of world. Consider Liz Norton's struggle, shortly after arriving in Santa Teresa in pursuit of Archimboldi, to put her finger on the undefined sense that something somewhere is out of joint: "Norton thought that something strange was going on, on the street, on the terrace, in the hotel rooms, even in Mexico City with those unreal taxi drivers and doormen, unreal or at least logically ungraspable, and even in Europe something had been happening, something she didn't understand" (Bolaño 2004, 151; 2008, 113). In a context where everything is out in the open, exposed like bleached bones under the desert sun, the secret of literature-which is inseparable from the irreducibly material character of its language - could introduce a kind of breach within the logic of globalization, a remainder irreducible to the distinction between concealment and revelation, presence and absence, surface and depth. The secret of literature holds the place of what remains uncounted and unseen when everything has been counted and exposed. The secret is not just nothing, not just the ruse of depth and concealment in a world where everything is already exposed; on the contrary-and this distinction means everything — it is part of the nothing-ing of language, which in turn brings us to the limit of power and its selfpresentation.

Could the question of the secret of literature, of the secret of the secret, open up a way of reading 2666 both with and against the grain of global war, with and against the neoliberal-administered globalization that is driven and abetted by a forgetting of worldliness? If 2666 still has something to say to us today seven years after its first publication, I propose that its contribution today does not stem from denunciations and exposés concerning the situation in Ciudad Juárez. This is not to say that the work of exposing hidden truths is not important; and it no doubt was important in the context of Juárez in the early twenty-first century when Bolaño was first beginning to write the novel. It is only to say that such work is not the proper task of literature; and, although there are of course literary works that take on such a task, that empirical fact does not make the work of exposing truth any more literary.

Whatever Bolaño may have wanted to do when he wrote 2666 - and that question of interest may well constitute a secret, both for criticism today and for the writer himself in his time-one of the novel's most significant contri- 
butions to the Latin American critical tradition is to place in question the adequacy of our traditional epistemological tools for understanding what is happening in our world today. As one of the cops in "The Part about the Crimes" puts it, "It's always important to ask questions and it's important to ask yourself why you ask the questions you ask. And do you know why? Because just one slip and our questions take us places we don't want to go.... Our questions are, by definition, suspect" (Bolaño 2004, 553; 2008, 442). For Heidegger there could be no better formulation of the way in which traditional ontology is compelled to miss the very target it takes aim at when it asks about the essence of the world. For Bolaño, this statement, uttered by a policeman whose moral legitimacy as representative of the law is by virtue of his chosen profession inherently suspect, has the power of suggesting that an unsurpassable gap separates everything that Ciudad Juárez names with respect to our world and our time on the one hand, and the critical vocabulary and modes of inquiry that we have at our disposal on the other hand. What Bolaño's fictional rendition of Santa Teresa offers us is not a rehashing of the old literary form of national allegory but rather a signaling of the possibility that our conceptual toolbox may turn out to be harboring some broken hammers. Santa Teresa is a literary site that withholds the secret of the world to the extent that the secret of literature-a fold where form and content, presentation and withdrawal become undecidable - is formally indistinguishable from the secret of the world, or the site of a breakdown in the global circuitry that at once calls attention to the fact that there is (es gibt) a world and illuminates the terrible specter of the end of the world (as we know it).

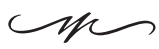

N O T E S

1. The conference, held at the State University of New York at Buffalo in May 2013, was organized by David Johnson in the Department of Comparative Literature. I am grateful to David for the invitation to present and to the many conference participants for the conversations that have subsequently helped me to reshape that paper and give it its current form.

2. Cuidad Juárez experienced a rapid population increase during the 1990 os due to large influxes of migrant and illegal immigrant workers seeking employment in the growing

This content downloaded from 129.79.32.222 on Mon, 17 Feb 2020 18:51:08 UTC All use subject to https://about.jstor.org/terms 
máquila industry; the population increase in combination with the temporary and precarious nature of máquila employment created an environment of social anonymity among new arrivals. This structure of anonymity in turn leaves young, single women especially vulnerable when facing a combination of new and old forms of violence, including the drug cartels, an increasingly corrupt police force, and a traditional marrianista culture for which women - and especially single women working outside the home-are viewed by many as morally suspect and as deserving of being put back in their place (González Rodríguez 2002; 2012).

3. See Marx 1977, especially the discussion of Adam Smith's quasi-theological account of "so-called primitive accumulation" in chapter 26 ("The Secret of Primitive Accumulation").

4. This is of course the classic account of the modern state found in Max Weber's lecture "Politics as a Vocation." See Weber $(2004,33)$.

5. Katechon is originally a theological concept that subsequently becomes part of the political philosophy of modernity. Paul's Second Epistle to the Thessalonians counsels the addressees not to act as if the Judgment Day were near since for that to come about there must first

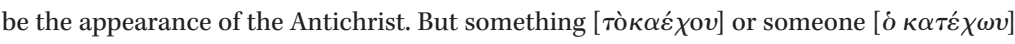
must currently be preventing the arrival of the Antichrist and it is that restraining force that receives the name katechon (that which withholds). As Carl Schmitt has noted, the modern state form in its various guises plays an analogous role, from state sovereignty in general defined as a restraining structure against the Hobbesian "war of all against all" to the Welfare State (arguably the last instance of the katechon) as a restraining device against the dual threats of disorder and anticapitalist movements that first emerged in the wake of global financial crisis in the 1930 (Schmitt 2003). Globalization and global war, meanwhile, together name a post-katechonic time during which all modern restraining devices have been removed.

6. In "The Part about the Critics" Archimboldi is described as "el gran tiburón negro" (Bolaño 2004, 25); in the context of the first part this metaphor generates an unavoidable literary comparison between the critics' self-interested-and potentially self-destructive-pursuit of Archimboldi and Ahab's pursuit of the great white whale. But, as we discover later, this same metaphorical repetition of Melville's Moby Dick will also have served to foreshadow the presentation of evil in later parts of Bolaño's novel. Melville's account of the recently finished novel in a letter to Nathaniel Hawthorne of November 17, 1851: "I have written a wicked book" (Melville 1993, 212).

7. Elsewhere in Being and Time Heidegger discusses the key role of anxiety, or fear in the absence of any determinate object, in bringing forth the experience of world and being. While I am unable to explore here the question of anxiety as it is present in certain sections of 2666 , the motif is connected to the kinds of questions I am raising here, especially in relation to Bolaño's play with an aesthetics of indeterminacy or withdrawal, which in my view can be linked to Borges's account of the aesthetic act as the "immanence of a revelation that does not take place."

8. As Valdés tells it in "Alone among the Ghosts," Bolaño benefited greatly from correspondence with the Mexican journalist Sergio González Rodríguez, whose Huesos en el desierto

This content downloaded from 
(2002) was the first sustained and detailed account of the serial killings (Valdés 2008). While Bolaño's questions indicated to González Rodríguez that he had already read extensively on the subject of the murders, it was González Rodríguez who first suggested to him that all of the murders could not reasonably be attributed to a single killer (who at that time was believed by many, including possibly Bolaño, to be Abdul Latif Sharif). The prospect of multiple serial killers reportedly forced Bolaño to abandon the idea of a single diabolical killer, who in 2666 would almost certainly have been the German expat Klaus Haas. The results of that correspondence included a radical transformation in Bolaño's last novel, which moves away from the classical pattern seen in earlier novels, in which the rational detective succeeds in solving this or that crime (Abel Ramírez in Estrella distante; Lima and Belano in Los detectives salvajes, etc.)

9. On "surface reading" see Best and Marcus (2009).

10. See Lacoue-Labarthe and Nancy (1988).

11. On the importance of literature for political modernity see Rancière (2004).

12. Of course the problem of the simultaneous unavoidability and impossibility of transcendence attends here. As Barbara Johnson taught us in her brilliant response to the LacanDerrida debate over Poe's "Purloined Letter," any critical attention to the movement of the signifier that believes itself to be leaving the signified behind is ultimately doomed to reproduce this very signified at the site of the signifier. See Johnson (1988, especially 232ff).

\section{R E F E R E N C E S}

Beckhusen, Robert. 2013. How Mexico's Drug Cartels Recruit Child Soldiers as Young as 11. Danger Room, March 28. www.wired.com/dangerroom/2013/o3/mexico-child-soldiers/ \#more-106341 (accessed March 29, 2013).

Best, Stephen; and Sharon Marcus. 2009. Surface Reading: An Introduction. Representations 108, no. 1: 1-21.

Bolaño, Roberto. 2004. 2666. Barcelona: Anagrama. . 2008. 2666 (English version), trans. Natasha Wimmer. New York: Farrar, Straus and Giroux.

2010. Bolaño en México. Interview with Mónica Maristain. La última entrevista a Roberto Bolaño y otras charlas con grandes escritores. Mexico: Axial. . 2013. El secreto del mal, ed. Ignacio Echevarría. Barcelona: Anagrama.

Borges, Jorge Luis. 2008. La muralla y los libros. In Otras inquisiciones, 9-13. Madrid: Alianza.

Bowden, Charles; and Molly Molloy. 2011. El Sicario: Confessions of a Cartel Hitman. New York: Random House.

Bussey, Jane. 2008. Political Reform Gave Push to Drug Lords' Rise in Mexico. McClatchey Newspapers, September 15. www.mcclatchydc.com/20o8/og/15/52320/political-reformgave-push-to.html (accessed March 29, 2013).

Derrida, Jacques. 1981. Dissemination. Chicago: University of Chicago Press. . 1992. This Strange Institution Called Literature. In Acts of Literature, ed. Attridge Derek, 33-75. New York: Routledge.

This content downloaded from 129.79.32.222 on Mon, 17 Feb 2020 18:51:08 UTC All use subject to https://about.jstor.org/terms 
2008. Genesis, Genealogies, Genres, and Genius. New York: Columbia University Press.

Fendt, Lindsay. 2012. Costa Rica Hosts CICAD Seminar on Tackling Region's Drug Problem. Diálogo, December 10. http://dialogo-americas.com/en_GB/articles/rmisa/features/ regional_news/2012/12/10/costa-rica-cicad (accessed October 16, 2013).

Galli, Carlo. 2010. Political Spaces and Global War, trans. Elisabeth Fay. Minneapolis: University of Minnesota Press.

González Rodríguez, Sergio. 2002. Huesos en el desierto. Barcelona: Anagrama. . 2012. The Femicide Machine, trans. Michael Parker-Stainback. Los Angeles: Semiotext(e).

Heidegger, Martin. 1971. The Origin of the Work of Art. In Poetry, Language, Thought, trans. Albert Hofstadter, 17-87. New York: Harper and Row.

. 2010. Being and Time, trans. Joan Stambaugh. New York: State University of New York Press.

Johnson, Barbara. 1988. The Frame of Reference: Poe, Lacan, Derrida. In The Purloined Poe: Lacan, Derrida, and Psychoanalytic Reading, ed. John P. Muller and William J. Richardson, 213-51. Baltimore: Johns Hopkins University Press.

Lacoue-Labarthe, Philippe; and Jean-Luc Nancy. 1988. The Literary Absolute, trans. Philip Barnard and Cheryl Lester. Albany: State University of New York Press.

Levinson, Brett. 2009. Cased Closed: Madness and Disassociation in 2666. Journal of Latin American Cultural Studies 18, no. 2-3: 177-91.

Marx, Karl. 1977. Capital. Vol. 1, trans. Ben Fowkes. New York: Vintage.

Melville, Herman. 1993. Correspondence. Evanston, IL: Northwestern University Press.

Nancy, Jean-Luc. 2007. The Creation of the World, or Globalization, trans. François Raffoul and David Pettigrew. Albany: State University of New York Press.

Rancière, Jacques. 2004. The Politics of Aesthetics, trans. Gabriel Rockhill. London: Continuum.

Schmitt, Carl. 2003. The Nomos of the Earth in the International Law of the Jus Publicum Europaeum, trans. G. L. Ulmen. New York: Telos.

Valdés, Marcela. 2008. Alone among the Ghosts: Roberto Bolaño's 2666. Nation, December 8. www.thenation.com/article/alone-among-ghosts-roberto-bolanos-2666? page $=0,0$ (accessed October 16, 2013).

Weber, Max. 2004. The Vocation Lectures. Indianapolis: Hackett.

This content downloaded from 129.79.32.222 on Mon, 17 Feb 2020 18:51:08 UTC All use subject to https://about.jstor.org/terms 
This content downloaded from 129.79.32.222 on Mon, 17 Feb 2020 18:51:08 UTC All use subject to https://about.jstor.org/terms 